Tropical Journal of Pharmaceutical Research July 2019; 18 (7): 1391-1396

ISSN: $1596-5996$ (print); 1596-9827 (electronic)

(C) Pharmacotherapy Group, Faculty of Pharmacy, University of Benin, Benin City, 300001 Nigeria.

\title{
Artemisinin derivative SM934, influences the activation, proliferation, differentiation and antibody-secreting capacity of $\beta$-cells in systemic lupus erythematosus mice via inhibition of TLR7/9 signaling pathway
}

\author{
Yajuan $\mathrm{Li}^{1}$, Lixin Zhao ${ }^{2}$, Xuehui Yang ${ }^{2}$, Jing Chen ${ }^{3}$, Wenjing $\mathrm{Xu}^{1}$, Quankai Gu ${ }^{4}$ \\ ${ }_{1}^{1}$ Department of Rheumatology, Tangshan Gongren Hospital, ${ }^{2}$ Department of Laboratory Medicine, Affiliated Hospital of North \\ China University of Science and Technology, Tangshan, ${ }^{3}$ School of Life Science, North China University of Science and \\ Technology, ${ }^{4}$ Department of Gastrointestinal Surgery, Tangshan Gongren Hospital, Tangshan 063000, China
}

${ }^{*}$ For correspondence: Email: usz23s@163.com

\begin{abstract}
Purpose: To study the influence of artemisinin derivative, SM934 on activation, proliferation, differentiation and antibody-secreting capacity of B cells of systemic lupus erythematosus (SLE) mice, and the underlying mechanism.

Methods: Female MRL/pr mice $(n=60)$ were randomly assigned to four groups of 15 mice each: SLE, $2.5 \mathrm{mg} / \mathrm{kg}$ SM934; $5 \mathrm{mg} / \mathrm{kg}$ SM934, and $10 \mathrm{mg} / \mathrm{kg}$ SM934 groups. Serum levels of interleukins 6, 10, 17 and 21 (IL-6, IL-17, IL-10 and IL-21) were determined. The secretions of immunoglobulins G and M (IgG and IgM) by $B$ cells were determined. The population of $B$ lymphocyte subtypes was determined flow cytometrically. The expressions of Blimp-1 and Bcl-6, Toll-like receptors 7 and 9 (TLR7 and TLR9) mRNAs were determined.

Results: SLE-induced upregulation of serum IL-10, IL-6, IL-17 and IL-21 was significantly and dosedependently reduced following a 2-month treatment with SM934 $(p<0.01)$. Treatment with SM934 significantly and dose-dependently accentuated B cell germinal center B cell populations, but significantly and dose-dependently decreased the populations of plasma and activated B cells $(p<$ 0.01). The splenic levels of $\lg G$ and $\lg M$ were decreased in a dose-dependent fashion after 8 weeks of treatment $(p<0.01)$. Artemisinin derivative SM934 decreased the expression of Blimp-1, and upregulated the expression of Bcl-6, both in a dose-dependent manner $(p<0.01)$. Moreover, SM934 decreased the mRNA expressions of TLR7 and TLR9 in a dose-based manner $(p<0.01)$.

Conclusion: Artemisinin derivative SM934 mitigates LSE syndromes by suppressing the TLR-induced $B$-cell stimulation and plasma cell generation.
\end{abstract}

Keywords: Systemic lupus erythematosus, $\beta$-cell, Antibodies, MRL/pr mice, TLR7/9 pathway

This is an Open Access article that uses a fund-ing model which does not charge readers or their institutions for access and distributed under the terms of the Creative Commons Attribution License (http://creativecommons.org/licenses/by/4.0) and the Budapest Open Access Initiative (http://www.budapestopenaccessinitiative.org/read), which permit unrestricted use, distribution, and reproduction in any medium, provided the original work is properly credited.

Tropical Journal of Pharmaceutical Research is indexed by Science Citation Index (SciSearch), Scopus, International Pharmaceutical Abstract, Chemical Abstracts, Embase, Index Copernicus, EBSCO, African Index Medicus, JournalSeek, Journal Citation Reports/Science Edition, Directory of Open Access Journals (DOAJ), African Journal Online, Bioline International, Open-J-Gate and Pharmacy Abstracts

\section{INTRODUCTION}

Systemic lupus erythematosus (SLE) is an autoimmune disease that affects several organs and systems. Its pathogenesis is linked to heredity, hormonal levels, environmental factors, drugs, and nutritional status [1]. The symptoms of SLE include fever, erythema on the cheek, 
oral bleeding, erosion or recurrent ulcers, joint swelling and pain, pleural effusion, organ dysfunction, nerve degeneration and hematological changes [2].

Women are more pre-disposed to SLE, and mortality associated with the disease shows a "double peak curve", that is, early death from lupus, and late death from myocardial infarction and other cardiovascular complications [3,4]. Women with SLE are over 5 times more likely to develop coronary artery disease (CAD) [5]. Adaptive and innate immune responses are implicated in SLE etiology. Toll-like receptor (TLR) is a transmembrane protein that plays a key role in adaptive and innate immune responses on binding to pathogens [6]. The TLR7/9 signaling pathway is linked to the activation and proliferation of B cells, and directly affects the development of SLE.

Artemisinin derivative SM934 is water-soluble and inhibits the expression of TLR7/9 [7-9]. The current investigation was aimed at studying the influence of SM934 on the activation, proliferation, differentiation and antibodysecreting capacity of B cells in mice with SLE, and the underlying mechanism.

\section{EXPERIMENTAL}

\section{Materials and reagents}

Female MRL/Ipr mice were supplied by the Animal Research Center of Nanjing University. Total RNA extraction kit, Trizol reagent, kits for reverse transcription and PCR, as well as ELISA kits for IL-10, IL-6, IL-17, IL-21, IgG and IgM were products of Wuhan Moshake Biotechnology Co., Ltd. Fetal bovine serum (FBS). QuantStudio 3 real time quantitative PCR instrument and primers were purchased from Thermo Fisher Scientific Co., Ltd. (China). Rabbit anti-TLR7, rabbit anti-TLR9, mouse and human IgG and IgM were obtained from Beijing Hapten and Protein Biomedical Institute, while SM934 was made available by Tangshan Gongren Hospital. This research was approved by the Animal Ethical Committee of Department of Gastrointestinal Surgery, Tangshan Gongren Hospital, Tangshan (approval no. 201813573), and was according to the guidelines of "Principles of Laboratory Animal Care" (NIH publication no. 85-23, revised 1985) [10].

\section{Mice and grouping}

This study made use of 4-month-old female $\mathrm{MRL} / / p r$ mice $(\mathrm{n}=60)$ weighing $20.0 \pm 2.0 \mathrm{~g}$. Four groups of mice were randomly assembled
(15 mice per group): SLE, $2.5 \mathrm{mg} / \mathrm{kg} \mathrm{SM934,} 5$ $\mathrm{mg} / \mathrm{kg} \mathrm{SM934}$, and $10 \mathrm{mg} / \mathrm{kg} \mathrm{SM934} \mathrm{groups.}$ Administration of SM934 was done orally once a day, while SLE group received $5.0 \mathrm{ml}$ of normal saline, once per day. The study lasted 8 weeks.

\section{Biochemical analysis}

At the end of 8 weeks, blood was collected from the eye veins of mice, and centrifuged at 3000 rpm for 15 min to obtain serum which was kept at $-80{ }^{\circ} \mathrm{C}$. Spleen tissue was also excised, washed with normal saline and used to prepare spleen lymphocyte suspension.

Serum IL-6, IL-10, IL-17 and IL-21 were assayed with ELISA kits. The secretions of IgG and IgM by $B$ cells were also determined using ELISA. The population of $B$ lymphocyte subtypes in mice spleen was determined flow cytometrically.

\section{Western blotting}

This was used to determine the expressions of Blimp-1 and Bcl-6. Spleen tissues collected from the mice were kept in liquid nitrogen at $-80{ }^{\circ} \mathrm{C}$. They were sliced into thin sections $(5 \mu \mathrm{m})$ using refrigerated microtome, and homogenized using Kinematica tissue pulverizer. The resultant tissue homogenate was washed twice with phosphatebuffered saline (PBS) and centrifuged at 10,000 $g$ at $4{ }^{\circ} \mathrm{C}$ for $30 \mathrm{~min}$. The protein concentration of the supernatant was determined using BCA assay kit. A portion of total tissue protein (20 - 30 $\mu \mathrm{g})$ from each sample was separated on SDSPAGE and transferred to a fixed polyvinylidene fluoride membrane at $110 \mathrm{~V}$ and $90{ }^{\circ} \mathrm{C}$ for 120 $\min$.

Subsequently, non-fat milk powder (3\%) in Trisbuffered saline containing $0.2 \%$ Tween-20 (TBST) was added with gentle shaking at $37^{\circ} \mathrm{C}$ and incubated to block non-specific binding of the blot. Incubation of the blots was performed overnight at $4{ }^{\circ} \mathrm{C}$ with primary antibodies of Blimp-1, Bcl-6 and glyceraldehyde 3-phosphate dehydrogenase (GAPDH) at a dilution of 1 to 500 . Then, the membrane was rinsed three times in TBS-T and subjected to incubation at room temperature for $1 \mathrm{~h}$ with goat anti-rabbit lgG secondary antibody conjugated with horse radish peroxidase.

The blot was developed using an X-ray film. Grayscale analysis of the bands was performed using ImageJ analysis software (Version 4.6.2). Respective protein expression levels were normalized to that of GAPDH which was used as a standard reference. 


\section{Quantitative real-time polymerase chain reaction (qRT-PCR)}

This was used to determine the levels of expression of TLR7 and TLR9 mRNAs. Total RNAs were isolated from portions of spleen homogenate using Trizol reagent and assessed spectrophotometrically. The RNAs were reversetranscribed to cDNAs, using random primers at $45^{\circ} \mathrm{C}$ for $2 \mathrm{~h}$. The samples were heated at $95^{\circ} \mathrm{C}$ for $10 \mathrm{~min}$. The PCR amplification of the reverse transcribed reaction mixture was carried out using $20 \mu \mathrm{L}$ reaction mixture and equal volume of SYBR Premix Ex TaqTM II. The PCR program was: pre-denaturation for half-a minute at $95^{\circ} \mathrm{C}$, denaturation at $95^{\circ} \mathrm{C}$ for $3 \mathrm{~s}$, annealing at $60{ }^{\circ} \mathrm{C}$ for $34 \mathrm{~s}$, and 50 cycles. Relative expression was quantified using Stratagene Mx3000P software, with GAPDH gene as internal reference.

\section{Statistical analysis}

Results are presented as mean \pm SEM, and were statistically analyzed using SPSS (version 19.0). Groups were compared using Students $t$-test. Statistical significance was fixed at $p<0.01$.

\section{RESULTS}

\section{Serum levels of IL-6, IL-10, IL-17 and IL-21}

The high levels of these cytokines in serum were significantly and dose-dependently reduced after

8 weeks of treatment with SM934 $(p<0.01$; Table 1).

\section{Effect of SM934 on number of B lymphocyte subsets}

Treatment with SM934 significantly and dosedependently elevated the population $B$ cells and germinal center B cells, while it significantly and dose-dependently reduced the population of plasma and activated B cells $(p<0.01)$. These results are shown in Table 2.

\section{Secretion of $\lg G$ and $\lg M$}

The splenic levels of $\lg G$ and $\lg M$ were significantly and dose-dependently reduced after 8 weeks of treatment with SM934 $(p<0.01$; Table 3).

Table 3: Splenic levels of IgG and IgM in the mice

\begin{tabular}{lcc}
\hline Group & IgG $(\mu \mathrm{g} / \mathrm{mL})$ & $\operatorname{lgM}(\mu \mathrm{g} / \mathrm{mL})$ \\
\hline SLE & $20.46 \pm 2.13$ & $16.37 \pm 2.36$ \\
$2.5 \mathrm{mg} / \mathrm{kg}$ & $14.75 \pm 1.55^{\mathrm{a}}$ & $12.97 \pm 2.11^{\mathrm{a}}$ \\
$\mathrm{SM934}$ & $12.34 \pm 1.21^{\mathrm{ab}}$ & $10.33 \pm 2.03^{\mathrm{ab}}$ \\
$5 \mathrm{mg} / \mathrm{kg} \mathrm{SM934}$ & $9.28 \pm 1.13^{\mathrm{abc}}$ & $7.38 \pm 1.85^{\mathrm{abc}}$ \\
$10 \mathrm{mg} / \mathrm{kg}$ & 138.75 & 50.04 \\
$\mathrm{SM934}$ & $<0.001$ & $<0.001$ \\
$F$ & & \\
$p$ & \multicolumn{2}{l}{}
\end{tabular}

Table 1: Comparison of serum IL-10, IL-6, IL-21 and IL-17 among the groups

\begin{tabular}{lcccc}
\hline Group & $\begin{array}{c}\text { IL-6 } \\
(\mathbf{p g} / \mathbf{m L})\end{array}$ & $\begin{array}{c}\text { IL-10 } \\
(\mathbf{n g} / \mathbf{m L})\end{array}$ & $\begin{array}{c}\text { IL-17 } \\
(\mathbf{n g} / \mathbf{m L})\end{array}$ & IL-21 (pg/mL) \\
\hline SLE & $128.46 \pm 25.31$ & $1.53 \pm 0.44$ & $5.76 \pm 0.75$ & $60.45 \pm 12.42$ \\
$2.5 \mathrm{mg} / \mathrm{kg} \mathrm{SM934}$ & $74.38 \pm 13.47^{\mathrm{a}}$ & $0.67 \pm 0.18^{\mathrm{a}}$ & $2.87 \pm 0.45^{\mathrm{a}}$ & $48.38 \pm 8.34^{\mathrm{a}}$ \\
$5 \mathrm{mg} / \mathrm{kg} \mathrm{SM934}$ & $55.29 \pm 10.16^{\mathrm{ab}}$ & $0.58 \pm 0.13^{\mathrm{ab}}$ & $2.34 \pm 0.38^{\mathrm{ab}}$ & $38.28 \pm 7.21^{\mathrm{ab}}$ \\
$10 \mathrm{mg} / \mathrm{kg} \mathrm{SM934}$ & $38.79 \pm 8.24^{\mathrm{abc}}$ & $0.45 \pm 0.12^{\mathrm{abc}}$ & $2.11 \pm 0.34^{\mathrm{abc}}$ & $32.46 \pm 6.56^{\mathrm{abc}}$ \\
$F$ & 91.74 & 56.00 & 167.23 & 28.38 \\
$P$-value & $<0.001$ & $<0.001$ & $<0.001$ & $<0.001$ \\
\hline${ }^{\mathrm{a}} P<0.01$, relative to SLE group; ${ }^{\mathrm{b}} p<0.01$, relative to $2.5 \mathrm{mg} / \mathrm{kg} \mathrm{SM934}$ group; ${ }^{\mathrm{c}} p<0.01$, relative to $5 \mathrm{mg} / \mathrm{kg}$ \\
SM934 group
\end{tabular}

Table 2: Number of B lymphocyte subsets in the different groups

\begin{tabular}{lcccc}
\hline Group & $\boldsymbol{\beta}$-cells $\left(\times \mathbf{1 0}^{\mathbf{6}}\right)$ & $\begin{array}{c}\text { Germinal center } \boldsymbol{\beta} \text { - } \\
\text { cells }\left(\times \mathbf{1 0}^{6}\right)\end{array}$ & $\begin{array}{c}\text { Activated } \boldsymbol{\beta}- \\
\text { cells }(\times \mathbf{1 0})\end{array}$ & $\begin{array}{c}\text { Plasma cells } \\
\left(\times \mathbf{1 0}^{6}\right)\end{array}$ \\
\hline SLE & $5.24 \pm 0.45$ & $4.46 \pm 0.45$ & $8.57 \pm 0.81$ & $15.67 \pm 1.25$ \\
$2.5 \mathrm{mg} / \mathrm{kg} \mathrm{SM934}$ & $6.33 \pm 0.46^{\mathrm{a}}$ & $5.53 \pm 0.54^{\mathrm{a}}$ & $7.45 \pm 0.78^{\mathrm{a}}$ & $12.34 \pm 1.12^{\mathrm{a}}$ \\
$5 \mathrm{mg} / \mathrm{kg} \mathrm{SM934}$ & $9.27 \pm 0.72^{\mathrm{ab}}$ & $8.62 \pm 0.82^{\mathrm{ab}}$ & $6.61 \pm 0.62^{\mathrm{ab}}$ & $9.43 \pm 0.77^{\mathrm{ab}}$ \\
$10 \mathrm{mg} / \mathrm{kg} \mathrm{SM934}$ & $18.29 \pm 1.21^{\mathrm{abc}}$ & $14.87 \pm 1.13^{\mathrm{abc}}$ & $5.13 \pm 0.43^{\mathrm{abc}}$ & $5.54 \pm 0.63^{\mathrm{abc}}$ \\
$F$ & 877.86 & 537.50 & 68.73 & 292.23 \\
$P$-value & $<0.001$ & $<0.001$ & $<0.001$ & $<0.001$ \\
\hline
\end{tabular}

${ }^{a} P<0.01$, relative to SLE group; ${ }^{0} p<0.01$, relative to $2.5 \mathrm{mg} / \mathrm{kg}$ SM934 group; ${ }^{\circ} p<0.01$, relative to $5 \mathrm{mg} / \mathrm{kg}$ SM934 group 


\section{Expressions of Blimp-1 and Bcl-6}

Treatment with SM934 brought about significant decrease in the expression of Blimp-1, while it caused significant upregulation of the expression of Bcl-6 $(p<0.01$; Figure 1$)$.

Table 4: Expression of Blimp-1 and Bcl-6 in mice ( $\mathrm{n}$, $\%)$

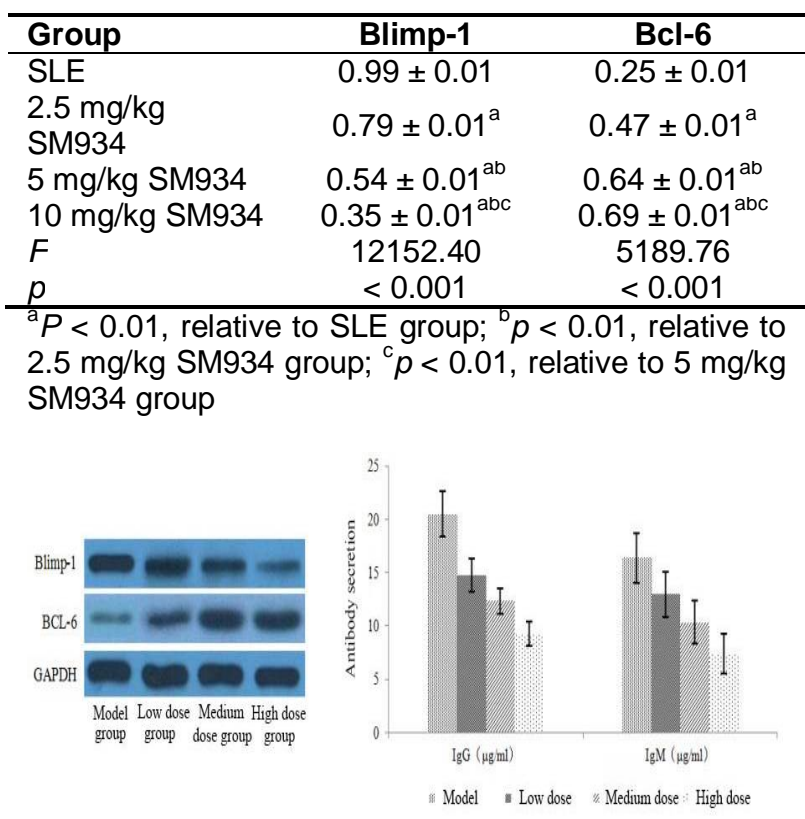

Figure 1: Effect of SM934 on the expressions of Blimp- 1 and Bcl-6 mRNAs

\section{Expressions of TLR7 and TLR9 mRNAs}

As shown in Table 5, the levels of expressions of TLR7 and TLR9 mRNAs were significantly and dose-dependently down-regulated after treatment with SM934 $(p<0.01)$.

Table 5: Levels of expression of TLR7 and TLR9 mRNAs ( $\mathrm{n}, \%$ )

\begin{tabular}{lcc}
\hline Group & TLR7 & TLR9 \\
\hline SLE & $0.98 \pm 0.01$ & $0.99 \pm 0.01$ \\
$2.5 \mathrm{mg} / \mathrm{kg}$ & $0.68 \pm 0.01^{\mathrm{a}}$ & $0.57 \pm 0.01^{\mathrm{a}}$ \\
SM934 & $0.58 \pm 0.01^{\mathrm{ab}}$ & $0.52 \pm 0.01^{\mathrm{ab}}$ \\
$5 \mathrm{mg} / \mathrm{kg} \mathrm{SM934}$ & $0.43 \pm 0.01^{\mathrm{abc}}$ & $0.44 \pm 0.01^{\mathrm{abc}}$ \\
$10 \mathrm{mg} / \mathrm{kg}$ & 8740.11 & 6667.29 \\
SM934 & $<0.001$ & $<0.001$ \\
$F$ & $P$-value &
\end{tabular}

${ }^{a} P<0.01$, relative to SLE group; ${ }^{\circ} p<0.01$, relative to $2.5 \mathrm{mg} / \mathrm{kg}$ SM934 group; ${ }^{c} p<0.01$, versus $5 \mathrm{mg} / \mathrm{kg}$ SM934 group

\section{DISCUSSION}

Lupus nephritis is characterized by abnormal expressions of cytokines [11]. Interleukin 6 (IL-6) enhances the formation, maturation and differentiation of $B$ cells [12]. Interleukin 10 (IL10 ) is an anti-inflammatory factor secreted by mononuclear macrophages, and it stimulates the proliferation of B cells, thereby promoting development of SLE. The current study investigated the influence of SM934 on the activation, proliferation, differentiation and antibody-secreting capacity of $B$ cells in mice with SLE, and the underlying mechanism.

Studies have shown that IL-10 is highly expressed in patients with SLE and lupus mouse models [13,14]. It has also been reported that in lupus patients, the expression of IL-17 is significantly upregulated, relative to healthy individuals, and that IL-17 aggravates symptoms of lupus disease via promotion of $\mathrm{B}$ cell activation [15]. Interleukin 21 (IL-21) is an important factor in humoral immunity; it promotes the proliferation, activation and secretion of antibodies by $\mathrm{B}$ cells, thereby aggravating symptoms of SLE [16]. Therefore, IL-10, IL-6, IL17 and IL-21 act on B cells and promote the incidence of SLE.

In this study, treatment with SM934 significantly and dose-dependently reduced the levels of these cytokines, an indication that SM934 may decrease the levels of these cytokines in MRL/lpr mice. It has been reported that the number of $B$ cells and germinal center B cells were significantly decreased, while the population activated plasma and B cells were significantly increased after treatment with SM934, leading to the conclusion that the increased number of plasma cells enhanced the antibody- secreting function of $B$ cells $[17,18]$.

The results obtained in this study showed that after 8 weeks of continuous administration of SM934, B cells and germinal center B cells were significantly and dose-dependently increased in population, while the population of activated $B$ and plasma cells were significantly and dosedependently reduced. These results are in agreement with those reported previously. The splenic levels of $\lg G$ and $\operatorname{lgM}$ were significantly and dose-dependently reduced after treatment with SM934.

Blimp-1 and Bcl-6 are a pair of transcription factors that interact with each other. Plasma cell transcription requires Blimp-1 which represses transcription of several genes linked with mature B cell phenotype [19]. In humans, Bcell lymphoma 6 protein (Bcl-6) regulates germinal center $B$ cells, thereby terminating them at germinal center stage, and blocking the differentiation of B cells into plasma cells [20]. The results of Western blotting showed 
significant and dose-dependent decrease in the expression of Blimp-1, while the expression of Bcl-6 was significantly and dose-dependently upregulated after treatment with SM934. Thus, SM934 may enhance the populations of $B$ and germinal center B cells, while significantly reducing the populations of plasma and activated B cells. It is likely that SM934 mitigates SLE by decreasing the secretion of $\lg G$ and $\lg M$, and that the degree of improvement may be dosedependent.

The generation and transformation of autoantigens and autoantibodies in SLE are closely linked to the TLR signaling pathway. It has been shown that TLR7 identifies singlestranded RNA (ssRNA) antigen [21], while TLR9 recognizes $\mathrm{CpG}$ fragment [22]. Both are expressed in B cells, and function synergistically on immune complex (antigen-antibody complex) to directly activate and accelerate the secretion of autoantibodies and plasma cells, thereby promoting the activation, proliferation and antibody-secreting capacity of B cells [23-25]. It has been reported that dihydroartemisin acts on the TLR signaling pathway to improve symptoms of SLE in MRL/lpr mice [26]. In this study, treatment with SM934 decreased the expressions of TLR7 and TLR9. These results suggest that SM934 may alleviate the symptoms of SLE by down-regulating the expressions of TLR7 and TLR9 mRNAs.

\section{CONCLUSION}

The effect of artemisinin derivative SM934 on SLE syndrome in mice is exerted via suppression of TLR-induced B-cell stimulation and plasma cell generation. It provides a breakthrough in the discovery of a series of new drugs for SLE syndrome.

\section{DECLARATIONS}

\section{Conflict of interest}

No conflict of interest is associated with this work.

\section{Contribution of authors}

We declare that this work was done by the authors named in this article and all liabilities pertaining to claims relating to the content of this article will be borne by the authors. Quankai $\mathrm{Gu}$ conceived and designed the study, Yajuan $\mathrm{Li}$, Lixin Zhao, Xuehui Yang, Jing Chen, Wenjing $\mathrm{Xu}$, Quankai Gu collected and analysed the data while Yajuan Li wrote the manuscript.

\section{Open Access}

This is an Open Access article that uses a funding model which does not charge readers or their institutions for access and distributed under the terms of the Creative Commons Attribution License (http://creativecommons.org/licenses/by/ 4.0) and the Budapest Open Access Initiative (http://www.budapestopenaccessinitiative.org/rea d), which permit unrestricted use, distribution, and reproduction in any medium, provided the original work is properly credited.

\section{REFERENCES}

1. Zhang J, Zhang BB, Cai $H$. Advances in the pathogenesis and biomarkers of systemic lupus erythematosus. Mod Med J 2017; 45(6): 887-890.

2. Yang PT, XU Y, Wang JN, Xiao WG. Systemic lupus erythematosus complicated with neuropsychiatric lupus. Chin J Pract Int Med 2015; 35(10): 828-830.

3. Zhou Y, Li ZJ. Systemic lupus erythematosus and infection. Chin Journal of Clin (Electronic Edition) 2016; 10(21): 3271-3275.

4. Chen W. Systemic lupus erythematosus with pregnancy. J Med Theory Pract 2017; 30(1): 32-33.

5. Qin Y, Gu ZF, Li LR, Sang Y. Sexual Dysfunction Status and Influencing Factors of Female Patients with Systemic Lupus Erythematosus. Chin Gen Pract 2016; 19(34): 4187-4195.

6. Gong L, Wang YZ. Research progress on TLRs in systemic lupus erythematosus. J Trop Med 2016; 16(1): 116-118.

7. Deng JY, Pan JC, Li HZ. Research Progress of B Cell Associated targets in systemic lupus erythematosus. Chin J Cell Mol Immunol 2016; 32(8): 1148-1150.

8. Wu Y, Wei T, Zuo J. Development of artemisinin drugs in the treatment of autoimmune diseases. Sci Bull 2016; 61(1): 37.

9. Wu Y, Tang $W$, Zuo J. Toll-like receptors: potential targets for lupus treatment. Chin Pharm Bull 2015; 36(12): 1395-1407.

10. World Health Organization. Principles of laboratory animal care. WHO Chron 1985; 39: 51-56.

11. Su J, Zhu J, Dong W, Long L, Long WB, Chen XX. Correlations between serum 25-hydroxyvitamin $D$ and cytokines in patients newly diagnosed with systemic lupus erythematosus. Chin J Cell Mol Immunol 2016; 32(12): 1671-1674.

12. Wu S, Liu S J, He Y, Deng LH. Expression and significance of interleukin- 6 in peripheral blood of patients with systemic lupus erythematosus. J Jinan Univ (Nat Sci Med Edition) 2016; 37(2): 164-168.

13. Gong ZK, Zhang JL. Relationships Between Traditional Chinese Medical Syndrome Types and Interferon- $\gamma$, Interleukin-2, Interleukin-4 and Interleukin-10 in Systemic Lupus Erythematosus. Chin J Dermatovenerol Integr Tradit West Med 2016; 15(1): 10-12.

Trop J Pharm Res, July 2019; 18(7): 1395 
14. Su DL, Lu ZM, Shen MN, Li X, Sun $L Y$. Roles of pro- and anti-inflammatory cytokines in the pathogenesis of SLE. J Biomed Biotechnol 2012; 2012(4): 347141.

15. Yang YK, Du JG, Zhu QF, Yu Q, Xu HX. Clinical Significance of Serum IL-10 and IL-17 in Patients with Systemic Lupus Erythematosus. J Mod Lab Med 2017; 32(3): 71-73.

16. Zheng $L T$, Zhang L, Zhao LD, Zhao $C$, Liu SY, Zhao $Y$, Zhang $H$, Zhang $F C$, Zeng $X F$. Expression, source and significance of interleukin-21 in patients with systemic lupus erythematosus and its correlation with interleukin17. Chin J Rheumatol 2016; 20(12): 801-805.

17. $\mathrm{Li} C L, \mathrm{Li} H \mathrm{HB}$. Advances in the relationship between regulatory $B$ lymphocytes and systemic lupus erythematosus. Beijing Med J 2015; 37(5): 480-482.

18. Yanaba K, Bouaziz J D, Matsushita T, Tsubata T, Tedder TF. The Development and Function of Regulatory $B$ Cells Expressing IL-10 (B10 cells) Requires Antigen Receptor Diversity and TLR Signals. J Immunol 2009; 182(12): 7459-7472.

19. Luo J, Niu X, Liu H, Zhang M, Chen M, Deng S. Upregulation of transcription factor Blimp1 in systemic lupus erythematosus. Mol Immunol 2013; 56(4): 574582.

20. Zhao LD, Liang D, Wu XN, Li Y, Niu JW, Zhou C, Wang $L$, Chen $H$, Zheng WJ, Fei $Y Y$, et al. Contribution and underlying mechanisms of CXCR4 overexpression in patients with systemic lupus erythematosus. Cell Mol Immunol 2016; 14(10): 842-849.

21. Fan $H$, Ren $D$, Hou Y. TLR7, a third signal for the robust generation of spontaneous germinal center $B$ cells in systemic lupus erythematosus. Cell Mol Immunol 2017; 15(3): 286-288.

22. Wang D, Zhang C, Zhou Z, Pei F. TLR9 polymorphisms and systemic lupus erythematosus risk: an update metaanalysis study. Rheumatol Int 2016; 36(4): 585-595.

23. Zorro $S$, Arias $M$, Riaño $F$, Paris $S$, Ramírez $L A$, Uribe $O$, García LF, Vásquez G. Response to ODN-CpG by $B$ Cells from patients with systemic lupus erythematosus correlates with disease activity. Lupus 2009 18(8): 718726.

24. Sieber J, Daridon C, Fleischer S J, Fleischer V, Hiepe F, Alexander $T$, Heine G, Burmester GR, Fillatreau $S$, Dörner T. Active systemic lupus erythematosus is associated with a reduced cytokine production by $B$ cells in response to TLR9 stimulation. Arthritis Res Ther 2014; 16(6): 477.

25. Wu DH, Fan YS, Xie GQ, Ji JQ, Xu L. Effect of jiedu Quyu Zishen recipe on Toll like receptor 9 signaling Pathway of Mouse Mononuclear macrophages. Chin J Integr Tradit West Med 2015; 35(4): 466-470.

26. Dong YJ, Li WD, Tu YY, Zhang HN, Zou WZ, Yang L, Lin $Z B$. The effects of DQHS on the pathologic changes in $B X S B$ mice lupus nephritis and the effect mechanism. Chin Pharmacol Bull 2003; 19(10): 1125-1128. 